\title{
КОНЦЕПТОСФЕРА СУЧАСНОЇ ГЕНДЕРНО МАРКОВАНОЇ ПЕРІОДИКИ: ПСИХОЛІНГВІСТИЧНИЙ АСПЕКТ ДОСЛІДЖЕННЯ
}

\author{
Мирослава Чорнодон \\ Донецький національний університет імені Василя Стуса \\ вул. 600-річчя, 21, 21021, Вінничя, Украӥна \\ e-mail: muroslavachornodon@ukr.net \\ https://orcid.org/0000-0002-9227-0993
}

У статті з'ясовано особливості концептосфери сучасної періодики для жінок і чоловіків. Проблема гендерної концептосфери розглядається у векторі психолінгвістичного аспекту, адже презентує результати контент-аналітичного дослідження обраних для вивчення журналів в психологічному і лінгвістичному розрізі. Проведене дослідження дало змогу визначити, які тлумачення концептів «жінка» та «чоловік» можна виявити на сторінках сучасної гендерно маркованої періодики і в такий спосіб детально проаналізувати гендерну концептосферу через призму видових характеристик концептів.

Визначено особливості вживання гендерних концептів у сучасній періодиці для жінок та чоловіків. Виявлено найчастіше вживані похідні цих макроконцептів, тобто їхні мікроконцепти, та детально їх проаналізовано. 3'ясовано, що видання для жінок та чоловіків насичені різноманітними гендерними концептами, які вживаються у різних контекстах.

Модель гендерних взаємин у засобах масової інформації відображено переважно у стереотипних образах чоловіка та жінки. Аналіз гендерних ролей жінки та чоловіка дає змогу глибше зрозуміти концепти «жінка», «чоловік», їхні різновиди - «мати», «дружина», «дочка», «батько», «син» тощо.

Гендерні стереотипи, які реалізовані в концептах-мінімумах та максимумах, використовуються в різних сферах життєдіяльності - в тому числі сферах діяльності, які ніби не пов'язані з проблемами взаємин між статями - тому, що індивід легко ідентифікує стать; стереотипні уявлення про чоловіків та жінок співвідносні з його особистим досвідом, а взаємини між статями сприймаються як найбільш очевидні, а відповідно, легітимні.

Загалом аналіз концептів-максимумів та концептів-мінімумів гендерного значення та їхніх характеристик здійснено в контексті гендерних стереотипів, які сформовані та функціонують у соціумі, систематизуючи реально існуючі репрезентації.

Ключові слова: гендер, концепт, концептосфера, контент-аналіз, психолінгвістика, аспект.

(C) Чорнодон М., 2020 
Постановка проблеми. Актуальність теми наукової статті зумовлена процесами пошуку нових концепцій та застосуванням нових підходів до вивчення гендерної концептосфери сучасної періодики для жінок і чоловіків в Україні. Вивчення гендерної концептосфери є актуальним, оскільки дозволяє виявити нові тенденції та ознаки сучасних гендерних образів. Враховуючи особливі риси гендерно маркованої періодики загалом та практичну відсутність комплексних наукових досліджень гендерної концептосфери зокрема, виникає потреба доповнення українського журналістикознавства саме цією темою.

Мета роботи полягає у з'ясуванні гендерної концептосфери у площині дослідження сучасної періодики для жінок і чоловіків

Для досягнення зазначеної мети були поставлені такі завдання: з'ясувати рівень наукового вивчення гендерної концептосфери в Україні; виявити особливості гендерного контенту та здійснити порівняльний аналіз сучасної періодики для жінок; виявити особливості гендерного наповнення та здійснити порівняльний аналіз сучасної періодики для чоловіків; розкрити питання гендерних ролей і стереотипів у досліджуваних виданнях; визначити особливості використання гендерних концептів на сторінках сучасної гендерно маркованої періодики; висвітлити на основі гендерних концептів багатогранність гендерних образів у сучасній періодиці для жінок та чоловіків.

Аналіз останніх досліджень та публікацій. Вивченню концептосфери присвячено небагато робіт. Найгрунтовнішою є докторська дисертація Л. Василик «Сучасна світоглядна публіцистика літературно-художніх видань у контексті історії української журналістики: концептосфера національної ідентичності». Захищено такі кандидатські дисертації із соціальних комунікацій, які стосуються вивчення концептів та концептуальних особливостей, зокрема праця М. Масімової «Концепція людини та світу в публіцистиці і художній творчості Умберто Еко», Н. Желіховської «Концептуально-тематичні особливості української публіцистики другої половини 80-х років ХХ століття». Щодо вивчення гендерних особливостей, то визначення гендеру в українській пресі досліджували Н. Остапенко, Н. Сидоренко, М. Скорик, В. Слінчук, Т. Старченко, Л. Ставицька, О. Сушкова, О. Пода, Я. Пузиренко, Л. Таран, О. Тараненко. Гендерні проблеми порушували у своїх наукових працях і русисти О. Дудоладова, О. Горошко, Л. Компанцева, О. Семиколєнова, Л. Синельникова, К. Піщикова.

Ця наукова стаття є кроком у висвітленні гендерної концептосфери сучасної періодики для жінок і чоловіків в Україні як невід'ємної складової українського суспільства.

Методологічна основа дослідження. У статті реалізовано комбінацію конкретно-історичного, структурно-типологічного, системно-функціонального методів. Застосовуються описовий та порівняльний методи, метод типологізації, моделювання. У статті також використаний метод контент-аналізу для вивчення гендерного контенту сучасних гендерно маркованих журналів. Саме він дав змогу кількісно визначити та дослідити особливості гендерної концептосфери на сторінках періодики для жінок і чоловіків.

Виклад основного матеріалу дослідження. Концептуальне сприйняття й тлумачення гендерного поняття «жінка», що висвітлюються на сторінках сучасної гендерно маркованої преси в Україні, потребує окреслення поліфункціональності ген- 
дерних інтерпретацій, осягнення метафоричного сприйняття цього образу та його ролі й призначення в суспільстві.

Цікаво детальніше дослідити гендерну концептосферу через призму видових характеристик концептів. Усі концепти умовно можна поділити на макро- та мікроконцепти або ж, іншими словами, на концепти-максимуми та концепти-мінімуми. Каркас гендерної концептосфери становлять два концепти, на котрих сконцентровано гендерні відносини в суспільстві - «чоловік» та «жінка», які позначаємо як макроконцепти або концепти-максимуми (Чухим, 2001).

Концепт, концептосфера включають гендерні ознаки, що уможливлює гендерний підхід для дослідження гендерного контенту сучасної періодики для жінок та чоловіків. Концептуальний аналіз сучасних гендерно маркованих видань у межах гендерної концептосфери дає змогу виявити й співвіднести метагендерні та гендерні концепти, що фігурують у суспільстві.

Дослідниця Л. Василик характеризує концепт-максимум як повне володіння значенням слова, що притаманне звичайному носію мови, якому реалія відома в усьому її обсязі. Такий концепт містить енциклопедичну інформацію, що розширює концепт-максимум за рахунок додаткових знань про об’єкт. Натомість концепт-мінімум означає неповне володіння значенням слова, що притаманне звичайному носію мови, якому відома сама реалія, але вона є начебто периферійною для його життєвої практики ${ }^{1}$.

Макроконцепт «жінка» умовно можна поділити на основні, тобто найчастіше вживанні у досліджуваних журналах мікроконцепти, а саме такі: кохана, коханка, мати, подруга, свекруха / теща, суперниця (див. табл. l).

(Таблиия 1)

Макроконцепт «жінка» та його похідні мікроконцепти

\begin{tabular}{l|c}
\hline \multicolumn{1}{c|}{ Мікроконцепти } & Кількість згадувань у виданнях (\%) \\
\hline Кохана & 26 \\
\hline Коханка & 23 \\
\hline Подруга & 14 \\
\hline Суперниця & 12 \\
\hline Мама & 11 \\
\hline Свекруха/теща & 9 \\
\hline Інші & 6 \\
\hline
\end{tabular}

Кохана - цей мікроконцепт, безумовно, вживається в контексті «чоловік/жінка» і відображає ставлення чоловіка до жінки, хлопця до дівчини. Мікроконцепт «кохана» в усіх випадках вживання позитивно забарвлений і характеризує жінку з найкращих її сторін «Щаслива жінка - кохана жінка» . Цей концепт відображає жінку, яка купається у любові та ласці чоловіка, для якої нічого не шкода «Все біля твоїх ніг, кохана моя, і я також». Часто концепт «кохана» замінюється такими синонімами: люба, мила, дорога, єдина. А також часто порівнюється з такими тваринами та птахами: кішка, зайчик, ластівка, лебідка.

Коханка - цей мікроконцепт вживається в негативному висвітленні, найчастіше - у тріаді «дружина - чоловік - коханка». I передовсім коханка порівнюється 3

1 Василик, Л. (2010), Світоглядна публіцистика сучасних літературно-художніх видань... 
такими тваринами: змія, гадюка, ящірка, жаба, а ці всі земноводні в порівняні характеризують жінку як підступну, підлу, хитру людину: «Змія на короткому ціпку»; «Подруга - гадюка, а чоловік - хамелеон».

Подруга - цей мікроконцепт висвітлюється і в позитивному, і в негативному забарвленні. По-перше, подруга - це вірна людина, готова завжди підставити своє плече, вислухати і дати пораду: «Подруга в біді не залишить». По-друге, концепт «подруга» змальовується на сторінках досліджуваних видань у контексті «псевдо подруги», яка готова дружити задля якоїсь мети, не завжди доброї: «Змія в овечій шкурі». Іноді ця псевдоподруга має на меті чоловіка, але не свого, а подруги. В такому випадку подруга виступає в образі суперниці.

Суперниця - це один $з$ найбільш вживаних у досліджуваній періодиці макроконцепт. I звісно, концепт «суперниця» вживається у гендерному співвідношенні «жінка - чоловік - жінка», де чоловік виступає у ролі головного призу, а дві жінки люто воюють за нього: «У кого буде супер-приз»; «Дві жінки та один чоловік».

Мама - цей мікроконцепт є одним 3 найбільш вживаних на сторінках досліджуваних видань, частіше - у журналах для жінок. Концепт «мама» вживається у позитивному (більше) та негативному (менше) смисловому навантаженні. У позитивному контексті мама - це, насамперед, турботлива, добра, ласкава, яка все розуміє $\mathrm{i}$ прощає, близька людина: «Моя мама - найкраща подруга»; «3 мамою не страшно в космос...». В негативному контексті концепт «мама» вживається доволі рідко, але у кількох журналах знайдено матеріали, в яких йдеться про маму так звану «зозулю», тобто біологічну маму, яка залишає свою дитину заради інших справ чи інтересів: «Зозуля кинула й полинула»; «Кар’єра згубила її, як маму». В негативному контексті «мама - зозуля» відображається тема абортів: «Вбивство заради мети». Отож, досліджуваний концепт «мама» має кардинально різні смислові навантаження. Але все-таки частіше концепт «мама» зображає світлий, чистий, прекрасний образ матеpi. Мама у періодиці для жінок і чоловіків часто порівнюється з берегинею та захисницею.

Свекруха/теща - ця групова категорія мікроконцептів є однією 3 найчастіше вживаних у досліджуваній періодиці для жінок та чоловіків. Спочатку розглянемо мікроконцепт «свекруха» - цей мікроконцепт не завжди вживається у позитивному контексті. Свекруха - мати чоловіка, яку часто зображають аж занадто всезнаючою і з постійним бажанням допомогти своєму синові та його сім’ї, і в такий спосіб втрутитись у життя молодої сім'ї, що не завжди допомагає, а навпаки через надмірну настирність шкодить. А ще перетворює свого сина на так званого «мамусиного синочка»: «Мій чоловік - мамусин синочок»; «Свекруха зруйнувала нашу сім’ю». У позитивному контексті свекруха зображається як подруга. Цей образ, безумовно, позитивний і допомагає читачкам знайти спільну мову й навіть здружитись зі свекрухою, якщо є деякі проблеми: «Свекруха: ворог чи подруга». Мікроконцепт «теща» часто вживається в комічному смисловому навантаженні, а тому часто є більше позитивним, аніж негативним. Цей концепт актуальний у виданнях і для жінок, і для чоловіків: «У тещі все під прицілом»; «У тещі під каблуком».

Для дослідження гендерної концептосфери виявлено основні гендерні концепти та їхні похідні, а також співвідношення між ними. З'ясовано, що гендерні концепти співіснують в тісній взаємодії між собою, тобто концепт «жінка» знаходить своє відображення у концепті «чоловік». Це висвітлено у такому категоріальному 
співвідношенні, як: «жінка - чоловік», яке своєю чергою поділяється на різні категорії: «дружина - чоловік», «мати - дитина» («мати - донька», «мати - син»), «жінка - свекруха», «дівчина - хлопець», «подруга - друг», «начальниця - підлеглий», «підлегла - бос». I ці взаємозв'язки у досліджуваних виданнях можуть вживатись 3 різним смисловим навантаженням, тобто у різних контекстах, як у позитивних, так і в негативних, а отже - виконувати різні міжособистісні функції, та інколи й соціальні ролі. Тобто, гендерно маркована періодика не обмежується висвітленням лише позитивного образу жінки.

У досліджуваних виданнях макроконцепт «чоловік» відображається у таких найчастіше вживаних мікроконцептах: коханий, батько, незнайомець, начальник, син, друг (див. табл. 2).

(Таблиия 2)

\section{Макроконцепт «чоловік» та його похідні мікроконцепти}

\begin{tabular}{l|c}
\hline \multicolumn{1}{c|}{ Мікроконцепти } & Кількість згадувань у виданнях (\%) \\
\hline Коханий & 30 \\
\hline Батько & 21 \\
\hline Незнайомець & 17 \\
\hline Начальник & 12 \\
\hline Син & 10 \\
\hline Друг & 7 \\
\hline Інші & 4 \\
\hline
\end{tabular}

Детальніше розглянемо ці концепти:

Коханий - цей мікроконцепт має і позитивне, і негативне забарвлення, тож, відповідно, вживається у гендерному концептуальному відношенні «чоловік - жінка». Концепт «коханий», звісно, частіше вживається у позитивному контексті. Йому притаманні такі риси, як ніжність, ласка, щедрість, турбота: «Коханий готовий на все»; «Коханий подарував зірку...». Але трапляються випадки, коли концепт «коханий» вживається у негативному контексті, а саме: «коханий / зрадник», «коханий / скупість», «коханий / робота» - «Зрада стерла нашу сім’ю»; «Мій коханий - скнара»; «Робота номер 1, а я...» Концепт «коханий» стосовно роботи вживається не тільки у негативному відображенні, тому що займає забагато часу, - більше, ніж жінка, але й у позитивному забарвленні - коли робота приносить великі прибутки і задоволення: «Мій коханий трудоголік з товстим гаманцем»; «Його робота - мої гроші».

Батько - цей мікроконцепт виокремлюємо як найчастіше вживаний у досліджуваних виданнях у співвідношенні «батько та дитина», тобто батько спільної з жінкою дитини. Цей мікроконцепт знаходить відображення у позитивному контексті, в цьому випадку образу батька притаманні такі риси, як: турбота, допомога, увага, щирість - «Наш татко - найкращий у світі»; «Батьківська увага безцінна для дитини». Також концепт «батько» знаходить відображення й у негативному висвітленні: «Батько - зрадник»; «Він (батько) залишив нас, коли я ще говорити не вміла».

Незнайомець - цей мікроконцепт використовується у найбільш вживаному відношенні (у нашому дослідженні категорії) «жінка та чоловік» і висвітлюється переважно у позитивному забарвленні: «Незнайомець із моїх снів»; «Незнайомець подарував 101 троянду». Цей концепт на сторінках досліджуваних видань (частіше для 
жінок) виключно позитивний і замінюється таким синонімом, як чарівник - «Вперше побачила чарівника на своєму порозі».

Начальник - цей мікроконцепт часто замінюється такими синонімами: бос, шеф, іноді старший колега - «Так, бос, я уважно слухаю». Цей мікроконцепт, безумовно, має і позитивне, і негативне відображення. У позитивному забарвленні концепт «начальник» вживається в контексті щедрого роботодавця: «На свою заробітну платню можу собі дозволити багато...» А у негативному - як суворого, владного, усе і всіх контролюючого тирана: «Начальник-тиран - мій страх». Варто зауважити, що мікроконцепт «тиран» не є одним із найбільш вживаних у досліджуваній періодиці для жінок і чоловіків, але попри це іноді вживається у контексті «жінка та чоловік», тобто чоловік, часто законний чоловік, який дозволяє собі погане, зневажливе, зле ставлення до своєї дружини: «Мій законний чоловік - справжній тиран»; «Деспот в домі». Відповідно, мікроконцепт «тиран» знаходить своє відображення у такому синонімі, як деспот. Мікроконцепт «законний чоловік», згадуваний вище у негативному контексті, ми не виділяємо в окрему групу найчастіше вживаних мікроконцептів, адже відносимо його до групи мікроконцепту «коханий», який раніше вже розглядали.

Син - цей мікроконцепт найчастіше вживається також у відношенні «жінка та чоловік», але концепт «жінка» своєю чергою у мікроконцепті «мати», тобто у ставленні сина до матері: «Мама - любов на все життя». А також цей мікроконцепт вживається у гендерному співвідношенні «мати - син - кохана», зазвичай у цьому випадку має частіше негативне, ніж позитивне забарвлення, адже концепт «чоловік» вживається у значенні «мамусин синочок» «На жаль, він виявився справжнісіньким мамусиним синочком».

Друг - цей мікроконцепт є одним із найчастіше згадуваних у досліджуваній періодиці і вживається у гендерних відношеннях «чоловік/жінка», «чоловік/чоловік»: «Мій друг - мій антибіотик» - у стосунках «чоловік/жінка», чоловік виступає у метафоричній ролі міцного, сильного плеча, такої собі подружки у чоловічому тілі: «Сильна у мене подруга - 100 кг і додому донести може, якщо треба...». А у стосунках «чоловік/чоловік» мікроконцепт «друг»- це насамперед сильний духом та міцний тілом чоловік, готовий завжди допомогти чи скласти компанію у тренажерній залі, а може й за кухлем пива: «Друг у біді не залишить»; «Справжній друг - залізо; «По пиву і про головне».

Макроконцепт «жінка» умовно можна поділити на основні, тобто найчастіше вживанні у досліджуваних журналах мікроконцепти, а саме такі: кохана $(26 \%)$, коханка (23\%), подруга (14\%), суперниця (12\%), мати (11\%), свекруха/теща (9\%), інші $(6 \%)$. Найповніше цей концепт виявляється у співвідношеннях I. - жінка та чоловік (30\%), II. - жінка і соціум (24\%), III. - жінка й духовність (20\%), IV. - жінка та сім'я $(14 \%)$, V. - жінка й краса (12\%).

У досліджуваних виданнях макроконцепт «чоловік» відображається у таких найчастіше вживаних мікроконцептах: коханий (30\%), батько $(21 \%)$, незнайомець (17\%), начальник (12\%), син (10\%), друг (7\%), інші (4\%). Детально розглянуто концепт «чоловік» у різних взаємодіях (співвідношеннях), а тому виділимо основні найчастіше вживані у досліджуваній періодиці відношення (категорії): «чоловік - кар'єра» $(28 \%)$, «чоловік і спорт» $(23 \%)$, «чоловік і жінка» $(19 \%)$, «чоловік і духовність» (16\%), «чоловік і сім'я» (14\%). 
Результати і перспективи подальших досліджень. Отож, висвітлення гендерного концепту «чоловік», як і концепту «жінка», на сторінках видань для чоловіків та жінок відрізняється. Наприклад, у жіночих виданнях чоловіка найперше описують у стосунках з жінками, лише потім - як професіонала своєї справи, майже не приділяється увага зовнішності чоловіка. Тобто внутрішня суть чоловіка має важливе значення для жінки (за матеріалами журналів). Що ж до концепту «чоловік» на сторінках видань для чоловіків, то саме зовнішності присвячена чимала частина публікацій. Також важливим для чоловіків $є$ правильне харчування, кар'єрний розвиток, успішність, статус у суспільстві. А висвітлення гендерного концепту «жінка» в гендерно маркованій періодиці підтверджує думку про те, що більшість сучасних жінок намагаються виявити себе і в роботі, і в стосунках з чоловіками, виконуючи різні соціальні ролі. Вони поєднують професійну та сімейну сферу життєдіяльності. Важливим $є$ духовний розвиток жінки як цілеспрямованої особистості, яка намагається підтримувати форму та стежити за своєю зовнішністю. Образ всебічно розвиненої жінки - головний на сторінках сучасних періодичних видань для жінок, що засвідчує аналіз їхнього контенту. Варто зауважити, що у журналах для чоловіків концепт «жінка» $€$ не менш важливим, і реалізується він у контексті «чоловік - жінка», а саме в аспекті роботи, захоплень, відпочинку, стосунків. Концепти «жінка» та «чоловік» співіснують в тісній єдності «чоловік - жінка». Стосунки з протилежною статтю є актуальною темою видань і для жінок, і для чоловіків.

Висновок. В основі гендерної концептосфери функціонують базові гендерні макроконцепти «жінка» й «чоловік», які вживаються у досліджуваній періодиці в різних співвідношеннях, залежно від того, які ролі виконують жінка чи чоловік у суспільстві. I саме від виваженості, вдумливості, відповідального добору гендерних характеристик, що подає гендерно маркована періодика, залежить формування сучасних та майбутніх гендерних образів, популяризація уявлення про ідеальних жінок і чоловіків, їхні потреби, можливості, обов'язки у сім'ї, на роботі, й загалом у всіх сферах життєдіяльності, а отже формується духовна і психологічна складова суспільства. Саме журнали для чоловіків підтримують теорію гендерної чоловічої ролі. А жіночі часописи, навпаки, демонструють, що представниці жіночої статі прагнуть бачити чоловіка більш ніжним, емоційним, спонтанним, здатним на непередбачувані вчинки, що не відповідає теорії гендерної чоловічої ролі, яку розробили Томпсон $i$ Плек. Спільне для обох типів видань те, що гендерні концепти не $є$ відокремленими: концепт «чоловік» згадується в контексті «чоловік - жінка», в контексті їхніх взаємин у різних аспектах життя. Отож, з'ясовано рівень наукового вивчення гендерної концептосфери, зокрема те, що концепт є багатовимірним, репрезентованим у мові комплексом, якому притаманна певна етнокультурна специфіка.

\section{СПИСОК ЛІТЕРАТУРИ}

1. Бацевич, Ф. С. (2007), Словник термінів міжкультурної комунікаиії. Довіра, Київ, $205 \mathrm{c}$.

2. Василик, Л. Є. (2010), Світоглядна публіщистика сучасних літературно-художніх видань: кониептосфера національної ідентичності, Буква, Чернівці, 431 с.

3. Gallagher, M. I. (2001), Gender setting: new agendas for media monitoring and advocacy, WACC, London, $217 \mathrm{p}$. 
4. Хамітов, Н. І. (2000), «Філософія статі», Філософська думка, 6 верес. 2000, с. 35-46.

5. Чухим, Н. Д. (2001). «Проблеми і перспективи феміністичної теорії», Гендер $i$ культура, 4 квіт. 2001, с. 94-101.

\title{
REFERENCES
}

1. Batsevich, F. S. (2007), Slovnik terminiv mizhkulturnö̈ komunikatsï̈, Dovira, Kyiv, 205 s.

2. Vasilik, L. (2010), Svitoglyadna publitsistika suchasnikh literaturno-khudozhnikh vidan: kontseptosfera natsionalnoï identichnosti : monogr., Bukva, Chernivtsi, $431 \mathrm{~s}$.

3. Gallagher, M. I. (2001), Gender setting : new agendas for media monitoring and advocacy, WACC, London, 217 p.

4. Khamitov, N. I. (2000; September 6), «Filosofiya stati», Filosofska dumka, 315, ss. 35-46.

5. Chukhim, N. Д. (2001; April 4,) «Problemi i perspektivi feministichnoï teoriï», Gender i kultura. 296, ss. 94-101.

\section{CONCEPTOSPHERE OF MODERN GENDER-LABELED PERIODICALS: PSYCHOLINGUISTIC ASPECT OF RESEARCH}

\author{
Myroslava Chornodon \\ Vasyl' Stus Donetsk National University. \\ S600th Str., 21, 21021, Vinnytsia, Ukraine \\ e-mail: muroslavachornodon@ukr.net \\ https://orcid.org/0000-0002-9227-0993
}

The article reveals the features of the contemporary periodicals conceptual sphere for women and men (based on examples from magazines of all-Ukrainian and regional purposes. The study made it possible to determine which interpretations of the concepts of «woman» and «man» can be found on the pages of modern gender-labeled periodicals, and thus analyze in detail the gender conceptual sphere through the prism of the specific characteristics of the concepts.

The features of the use of gender concepts in modern periodicals for women and men were determined. The most frequently used derivatives of these macroconcepts were identified and analyzed in detail. It has been found that publications for women and men are full of various gender concepts that are used in different contexts.

In general, the analysis of the concept-maximums and concept-minimums of gender and their characteristics is carried out in the context of gender stereotypes that have been formed and function in the society, systematizing the actual presentations.

The study of the gender concept is relevant because it reveals new trends and features of modern gender images. Taking into account the special features of gender-labeled periodicals in general and the practical absence of comprehensive scientific studies of the gender concept in particular, there is a need to supplement Ukrainian science with this topic.

Gender psychology, which is served by methods of various sciences, primarily sociological, pedagogical, linguistic, psychological, socio-psychological. Let us pay attention to linguistic and psycholinguistic methods in gender studies. Linguistic methods complement intelligence research tasks, associated with speech, word and text. Psycholinguistic methods 
used in gender psychology (semantic differential, semantic integral, semantic analysis of words and texts), aimed at studying speech messages, specific mechanisms of origin and perception, functions of speech activity in society, studying the relationship between speech messages and gender properties participants in the communication, to analyze the linguistic development in connection with the general development of the individual.

Nowhere in gender practice there is the whole arsenal of psychological methods that allow you to explore psychological peculiarities of a person like observation, experiments, questionnaires, interviews, testing, modeling, etc.

The methods of psychological self-diagnostics include: the gender aspect of the own sociopsychological portrait, a gender biography as a variant of the biographical method, aimed at the reconstruction of individual social experience. In the process of writing a gender autobiography, a person can understand the characteristics of his gender identity, as well as ways and means of their formation.

Socio-psychological methods of studying gender include the study of socially constructed women's and men's roles, relationships and identities, sexual characteristics, psychological characteristics, etc. The use of gender indicators and gender approaches as a means of sociopsychological and sociological analysis broadens the subject boundaries of these disciplines and makes them the subject of study within these disciplines.

And also, in the article a combination of concrete-historical, structural-typological, system-functional methods is implemented. Descriptive and comparative methods, method of typology, modeling are used. Also used is a method of content analysis for the study of gender content of modern gender-stamped journals. It was he who allowed quantitatively to identify and explore the features of the gender concept in the pages of periodicals for women and men.

A combination of historical, structural-typological, system-functional methods is also implemented in the article. Descriptive and comparative methods, method of typology, modeling are used. A method of content analysis for the study of gender content of modern gender-labeled journals is also used. It allowed to identify and explore the features of the gender concept quantitatively in the periodicals for women and men.

The conceptual perception and interpretation of the gender concept «woman», which is highlighted in the modern gender-labeled press in Ukraine, requires the elaboration of the polyfunctionality of gender interpretations, the comprehension of the metaphorical perception of this image and its role and purpose in society.

The concept, the concept sphere is gendered, enabling a gendered approach to researching the gender content of contemporary periodicals for women and men. Conceptual analysis of contemporary gender-stamped publications within the gender conceptual sphere allows to identify and correlate the meta-gender and gender concepts that appear in society.

The concept and the conceptual sphere are gendered, enabling a gendered approach to researching the gender content of contemporary periodicals for women and men. Conceptual analysis of contemporary gender-labeled publications within the gender conceptual sphere allows us to identify and correlate the meta-gender and gender concepts that appear in society.

Key words: gender, concept, concept sphere, content analysis, psycholinguistics, aspect. 